\title{
Outcome of Snodgrass (Tabularized Incised Plate) in Repair of Primary Distal Hypospadias with Narrow Urethral Plate
}

\author{
MOSAB I. EL-DEEB, M.Sc.; SALAH A. NAGLA, M.D.; MOHAMED O. ABO FARHA, M.D. and \\ AYMAN A. HASSAN, M.D.
}

The Department of Urology, Faculty of Medicine, Tanta University

\begin{abstract}
Background: Options for urethroplasty in children with hypospadias can be classified as tubularizations of the urethral plate, skin flaps and grafts. Throughout the history of surgery for this condition flaps have been most commonly used, but in the past 10 years incision and tubularization of the urethral plate (tubularized incised-plate, TIP) has rapidly gained popularity for correcting distal, proximal and re-operative hypospadias. TIP potentially simplifies both decision-making and surgical technique, and has a low complication rate with better cosmetic results. However, careful attention to surgical details and awareness of contraindications to the procedure are needed to achieve optimal results.
\end{abstract}

Aim of Study: Outcome of Snodgrass (Tabularized Incised Plate) in repair of primary distal hypospadias with narrow urethral plate.

Patients and Methods: Twenty patients with primary distal and midpenile hypospadias were enrolled for repair with Snodgrass technique.

Demographic data, hereditary relationship, urethral plate length and width, glans width, and intraoperative time were recorded and post-operative early and late complications were observed for parents and surgeon satisfaction.

Results: Between the 20 patients, only three patients developed post-operative complication one was urethrocutaneous fistula and two showed meatal stenosis with success rate $85 \%$.

Conclusion: Tubularized incised plate in repair of primary distal and midpenile hypospadias successfully fulfils all traditional hypospadias repair criteria. It offers a viable option in the management of primary hypospadias with a narrow urethral plate.

Key Words: Hypospadias-TIP - Urethral plate-Cosmesis - Outcome - Repair.

\section{Introduction}

HYPOSPADIAS is a common genitourinary anomaly affecting $3.5-4.5$ per 10000 live births, either treated or untreated, can have functional,

Correspondence to: Dr. Mosab I. El-Deeb, E-Mail:dr.mosab eldeeb@yahoo.com. cosmetic and psychosexual consequences extending into adulthood [1].

The goals of hypospadias surgery include the establishment of a straight penis with a urethral meatus at the glans tip, the establishment of a wellvascularized neourethra of adequate caliber with a solid, straight urinary stream and the achievement of normal sexual function when the patient reaches maturity [2]

TIP urethroplasty has gained widespread acceptance for repairing distal hypospadias. The technique is simple, versatile and produces a good cosmetic result; however, several technical issues, including the problem of meatal or neourethral complications and the need for regular urethral dilatation, have been pointed out $[3,4]$. It may be anticipated that this problem would be potentially more significant in patients with a flat and narrow urethral plate than in patients with a deeply grooved and wide urethral plate [4]

TIP repair was introduced in 1994, and is considered the procedure of choice in management of distal hypospadias by most surgeons [я. The technique relies on an incision of the urethral plate to permit a tension-free tubularization of the neourethra. The mechanism of healing of the incisedplate is debatable. Snodgrass postulated that healing occurs by re-epithelialization, with no evidence of neourethral stenosis or stricture formation, whereas many others consider that it heals by epithelial creeping, which theoretically increases the incidence of complications because of healing by primary intention if allowed to contract $[3,6,7]$

In hypospadias, the urethral plate is a vascularised tissue, rich in nerve supply, and has good muscular backing. These properties render the urethral plate extremely suitable for hypospadias 
repair. Tubularized plate urethroplasty (tip) procedures employ the urethral plate as sole part of the neourethra formation with favorable outcomes [8]

Although the suitability of the urethral plate to correct hypospadias in straight penis with a good urethral plate width, but the small urethral plate was discussed to have multiple complications [9]

The urethral plate width as a sole factor in the success of repair still a debatable subject. In the present study, we evaluated the surgical results of this procedure and extended the indications in primary hypospadias repair with poor urethral plate with and without minimal ventral curvature.

\section{Patients and Methods}

This prospective study included 30 patients who were admitted into Urology Department, Tanta University Hospitals suffering from distal and midpenile hypospadias during the period from March 2017 to August 2018.

Our study was approved by the local Ethics and Research Committee at Tanta Faculty of Medicine under number 31283/12/16; informed consent was obtained from all participants before enrollment in the study.

\section{Patient selection:}

- Inclusion criteria:

- Primary distal and mid-penile hypospadias.

- Children older than 4 months.

- Urethral plate less than $8 \mathrm{~mm}$.

- Non-circumcised penis.

- Exclusion criteria:

- Redo hypospadias.

- Penile curvature which needs correction.

- Chronic penile skin diseases.

- Associated other genital anomalies.

- Circumcised penis.

- Glandular hypospadias.

- Urethral plate $8 \mathrm{~mm}$ or more.

- Proximal hypospadias.

30 patients (mean age at 24 months, range between 6.0 to 63.0) have undergone the Snodgrass procedure at our institution. All patients have narrow urethral plate less than $8 \mathrm{~mm}$ that was measured pre-operatively (Fig. 1).

All operations were performed by a single pediatric urologist. Intravenous antibiotic prophylaxis was given before the induction of general anesthesia (cefuroxime $3 \mathrm{mg} / \mathrm{kg}$ iv) then caudal block was done to reduce the post-operative pain.

A circumferential subcoronal skin incision is made $1-2 \mathrm{~mm}$ proximal to the meatus then two parallel incisions running from the para-meatal skin to the tip of the glans were made. Degloving of the penile skin was then done, next step include a relaxing incision is made in the midline by using scalpel or scissors from within the meatus to the end of the plate. The edge of the distal glans should not be incised to avoid meatal stenosis. The depth of this relaxing incision depends on the plate width and depth but in all cases extends down to the corpora cavernosa.

The neourethra is closed using a fine suture ( $7 / 0$ vicryl suture) over $8 \mathrm{~F}$ nelaton catheter. The first layer used to be a continuous subcuticular one and reinforced with second interrupted layer. A vascularized flap of the dartos fascia was taken to avoid fistula formation. The glans flaps are closed with a good cosmetic appearance of the glans and the neomeatus (Fig. 2).

Antibiotic soaked gauze and light dressing were applied for three days (Fig. 3) and the catheter was left indwelling in a diaper for 7-10 days.

\section{Postoperative care:}

The repair was done on an out-patient base and all the patients were discharged on the first postoperative. The dressing was removed after 2 days and the urethral catheter was removed after 7-10 days of the operation. The children were observed for urinary stream. During the follow-up, the penis was reviewed for complications such as wound infection and wound dehiscence.

\section{Follow-up:}

The patients were followed-up every 2 months for the first 6 months, then every 6 months for the next year and annually thereafter. Success was defined as having a functional urethra without fistula, stricture, or residual curvature and having a cosmetically pleasing glandular meatus and phallus.

\section{Results}

A total 30 patients enrolled in this study underwent snodgrass repair.

The external meatus was: Coronal in 11 , distal penile in 17 and mid penile in 2 patients. All selected cases in this study had a narrow urethral 
plate (equal or less than $8 \mathrm{~mm}$ in width) ranging from 4.0 to $7.0 \mathrm{~mm}(5.55 \pm 1.23)$ with ( $p$-value $=0.158$ ). Glans width ranged from 13.0 to 18.0 $(16.40 \pm 0.94)$ with $(p$-value $=0.972)$. Urethral plate length ranged from10.0 to $15.0(13.15 \pm 1.90)$. ( $p$ value $=0.316)$. The operative time in the whole study was measured in minutes and ranged from 55.0 to $95.0 \mathrm{~min}$ with a mean $74.0 \pm 11.43 \mathrm{~min}$.

No intra operative complications were reported in both groups.

Early postoperative complications that occurred during the first two weeks included wound dehiscence occurred in one patient $(3.3 \%)$ and catheter blockage in one patient (Table 1). Late postoperative complications included urethrocutaneous fistula in one patient $(3.3 \%)$ the fistula was small and located at sub coronal area without meatal stenosis.

Table (1): Early post-operative complications.

\begin{tabular}{lcl}
\hline Early comp & No. & $\%$ \\
\hline No & 28 & 93.3 \\
Dehiscence & 1 & 3.3 \\
Catheter blockage & 1 & 3.3 \\
\hline
\end{tabular}

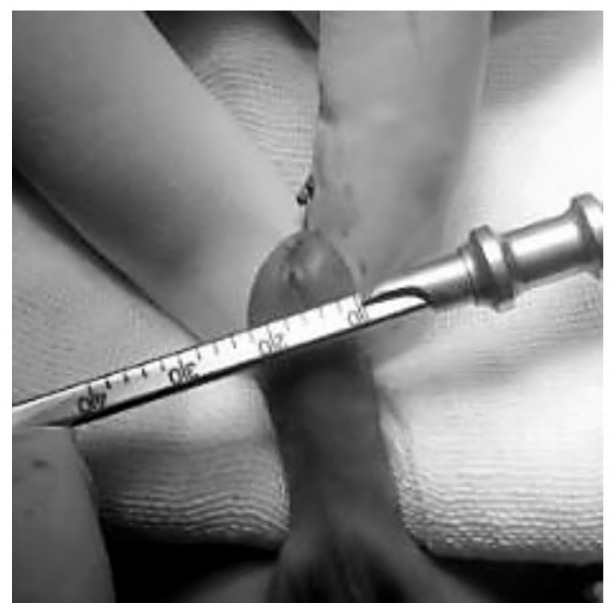

Fig. (1): Measurement of urethral plate width.

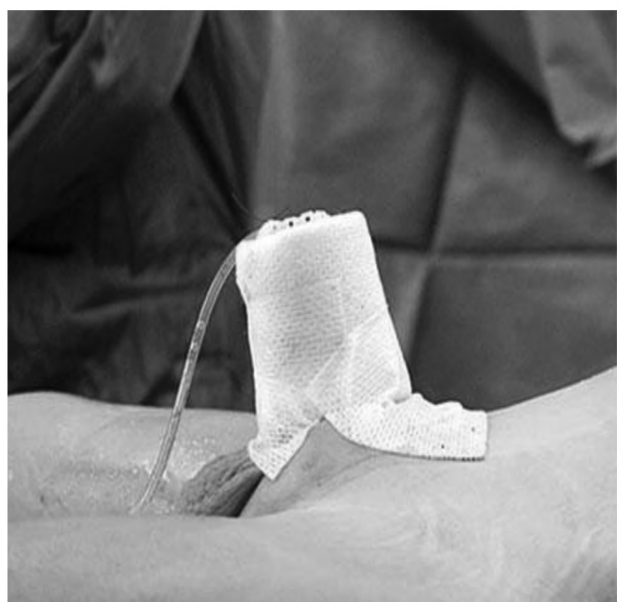

Fig. (3): Postoperative dressing.
The fistula was repaired after 6 months later by simple closure.

Another 2 patients had meatal stenosis $(6.6 \%)$, both of them responded to regular dilatation (Table 2).

The study results showed that 27 of the 30 patients included in the study had successful repair (as regard criteria of success) (Fig. 4) the overall late post-operative complications rate was $10 \%$.

\section{Statistical analysis:}

Statistical analysis was done using IBM SPSS software version 20.0. (Armonk, NY: IBM Corp). Categorical variables were compared with the chisquared test and numerical variables were compared with ANOVA test. $p<0.05$ was considered statistically significant.

Table (2): Late post-operative complications.

\begin{tabular}{lcl}
\hline Late comp & No. & $\%$ \\
\hline No & 27 & 90.0 \\
Fistula & 1 & 3.3 \\
Meatal stenosis & 2 & 6.6 \\
\hline
\end{tabular}

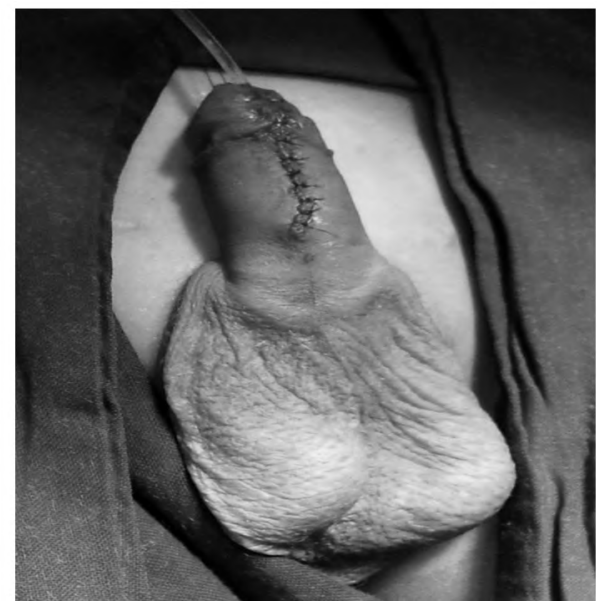

Fig. (2): Post-operative image of Snodgrass method.

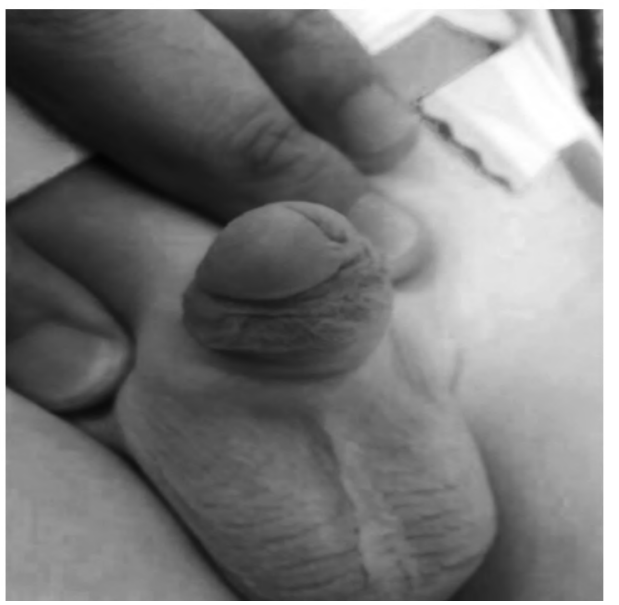

Fig. (4): Follow-up after 6 months. 


\section{Discussion}

Perhaps no surgical concern in history has inspired such widespread and varied opinion with regard to management as has hypospadias [10]

More than 100 different types of procedures have been described for the repair of this anomaly. Irrespective of the technique used. The goals of repair remain unchanged. A straight penis, with a urethral meatus in the normal position on the glans, a neourethra of adequate homogeneous caliber, with a solid, straight urinary stream and adequate skin coverage of the phallus [11].

The urethral plate shape and width are generally evaluated when the TIP repair is opted for the management of hypospadias. Holland and Smith [12] and Nguyen et al., [13] where statistically significant higher fistula was found in patients with urethral plate $<8 \mathrm{~mm}$ width. However, Nguyen et al., [13] reported 1 case $(3.3 \%)$ over 30 cases with narrow urethral plate versus one case $(0.7 \%)$ over 129 cases with urethral plate $>8 \mathrm{~mm}$; therefore, the result was statistically insignificant. The higher fistula rate with narrow urethral plate occurs because of the fact that midline incision of the urethral plate is not enough to create a neourethra with too much width around 8Fr catheter; as a consequence, the urethral plate makes the anastomoses under tension. Therefore, tubularization with tension on suture line increases the incidence of fistula formation in cases with narrow urethral plate. But sufficient incision of urethral plate makes it easier to tabularize over a catheter as shown in our results with success rate $85 \%$.

\section{Conclusion:}

Snodgrass (tubularized incised plate) urethroplasty is a simple, quick, single stage procedure suitable both for mid and distal penile hypospadias repair. It provides excellent functional neourethra, cosmetically normal looking glans and meatus and is associated with very few complications. It offers a viable option in the management of primary hypospadias with a narrow urethral plate. It has become the preferred technique of hypospadias without extensive chordee, in primary repair of distal and mid penile in our institution.

\section{References}

1- AG, eds.: Pediatric surgery. 5 th edn. Philadelphia: Mosby Year Book Inc., 1761-81, 1998.

2- SNODGRASS W.T.: Hypospadias. In: Wein A.J., Kavoussi L.R., Novick A.C., Partin A.W., Peters C.A., et al. Campbell-Walsh Urology. $10 \mathrm{t}^{\mathrm{h}}$ ed. Philadelphia: ElsevierSaunders, 3503, 2012.

3- ELBAKRY A.: Tubularized-incised Duckett JW, Baskin LS. Hypospadias. In: O. Neill J.A., Row M.I., Grosfeld J.L., Fonklsrud E.W., Coran urethral plate urethroplasty: Is regular dilatation necessary for success? BJU Int., 84: 683-8, 1999.

4- ELBAKRY A.: Further experience with the tubularizedincised urethral plate technique for hypospadias repair. BJU Int., 89: 291-4, 2002.

5- SNODGRASS W.T.: Tubularized incised plate urethroplasty for distal hypospadias. J. Urol., 151: 464-5, 1994.

6- SNODGRASS W.T.: Does tubularized incised plate hypospadias repair create neourethral strictures? J. Urol., 162: 1159-61, 1999.

7- HAYES M.C.C. and MALONE P.S.: The use of dorsal buccal graft with urethral plate incision (Snodgrass) for hypospadias salvage. BJU Int., 83: 508-9, 1999.

8- ERol A., et al: Anatomical studies of the urethral plate: Why preservation of the urethral plate is important in hypospadias repair. Br. J. Urol. Int., 85: 728-732, 2000.

9- HOLLAND A.J., et al.: Effect of the depth and width of the urethral plate on tubularized incised plate urethroplasty. J. Urol., 164: 489-491, 2000.

10- BORER J.G. and RETIK A.B.: Hypospadias. In: Wein A.J., Kavoussi L.R., Novick A.C., Partin A.W., Peters C.A., editors. Campbell-Walsh Urology. 9 th ed. Philadelphia, PA: Saunders Elsevier, 3703-44, 2007.

11- DUCKETT J.W.: Forward. Symposium on hypospadias. Urol. Clin. North. Am., 8: 513-20, 1981.

12- HOLLAND A.J. and SMITH G.H.: Effect of the depth and width of the urethral plate on tubularized incised plate urethroplasty. J. Urol., 164: 489-491, 2000.

13- NGUYEN M.T., SNODGRASS W.T. and ZAONTZ M.R.: Effect of urethral plate characteristics on tubularized incised plate urethroplasty. J. Urol,. 171: 1260-1262, 2004. 


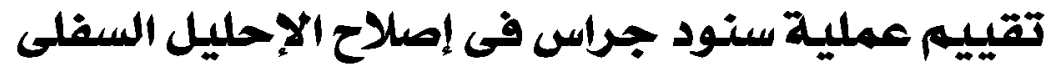

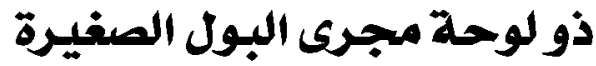

الإحليل السفلى هو تشوه خلقى شائع جداً فى الجهاز البولى التناسلى حيث تتواحد فتحة مجرى البول الخارجية فى السطح السفلى للقضيب أو بين كيس الصفن أو فى منطقة العجان ويؤثر على واحد من كل ثلاثمائة مولود ذكر.

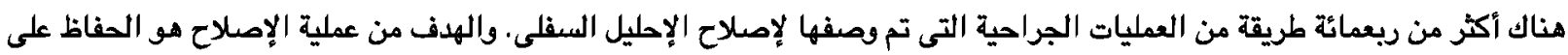
الشكل الطبيعى للقضيب مع وجود فتحة مجرى البول في مقدمة الحفشة والتدفق الطبيعى للبول والحفاظ على الإلى الوظيفة الجنسية المثلى خلال مرحلة البلوغ.

وتعتبر شريحة مجرى البول المشقوقة من العمليات الاكثر شيوعاً والتى تستخدم لإصلاح الإحليل السفلى لكونها تقلل من التوتئر على مجرى التها البول الجديد وبالمقارنة مع العمليات الأخرى المستخدمة تعتبر من الطرق ذات نسبة مضاعفات المفات قليلة ويمكن أجراؤها على مرحلة واحدة. الهدف من هذه الدراسة المستقبلية تقييم عملية سنود جراس فى إصلاح الإحليل السفلى ذو لوحة مجرىالبول الصغيرة. تم إجراء هذه الدراسة على ثلاثون مريضاً يعانفن من الإحليل السفلى الطرفى والمتوسط. على مدار ما يقارب عام ونصف لوحظ أن المضاعفات التى حدثت فى حالات إصلاح الإحليل الطرفى والمتوسط كانت نسبة صغيرة تصل إلى . ويناءً على ما سبق فإنتا نوصى بإستخدام تقنية شريحة مجرى البول المشقوقة فى إصلاح الإحليل السفلى الطرفى والمتوسط. 